TAPROBANICA, ISSN 1800-427X. August, 2014. Vol. 06, No. 02: pp. 100-109, pls. 9-11.

(C) Research Center for Climate Change, University of Indonesia, Depok, Indonesia

\& Taprobanica Private Limited, Homagama, Sri Lanka

http://www.sljol.info/index.php/tapro

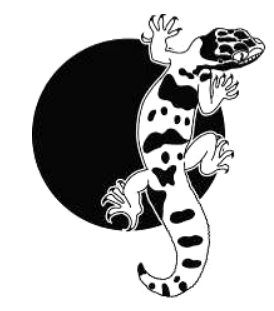

\title{
POLLINATION ECOLOGY OF Lumnitzera racemosa WILLD. (COMBRETACEAE), A NON-VIVIPAROUS MANGROVE TREE
}

\section{A. J. Solomon Raju ${ }^{1,3}$, Rajendra Kumar ${ }^{2}$ and B. Rajesh ${ }^{1}$}

\author{
${ }^{1,3}$ Department of Environmental Sciences, Andhra University, Visakhapatnam 530003, India \\ ${ }^{2}$ Ministry of Environment and Forests, Paryavaran Bhavan, CGO Complex, Lodhi Road, New Delhi 110003, \\ India \\ ${ }^{3}$ Email: ajsraju@yahoo.com
}

\begin{abstract}
Lumnitzera racemosa is a non-viviparous evergreen mangrove tree species. It is a massive bloomer from mid-July to mid-August. The flowers are bisexual, self-compatible, self-pollinating and exhibit a mixed breeding system. The plant is temporally dioecious with marked protandry and a non-receptive stigma on day one of anthesis with a receptive stigma on days two and three. Fruit set is approximately $90 \%$ due to self and cross-pollination. The floral characters are related to pollination by generalized flower-visiting insects, notably actinomorphy, white spreading petals, limited but easily accessible nectar, and position of stamens. Pollinators include bees, wasps and butterflies. Fruits are invariably 1-seeded despite the presence of 3-5 ovules. Natural regeneration is low perhaps due to abortion of embryos or the feeding of embryos by small grubs. Fallen mature fruits become fibrous in water and this may aid dispersal in the sea. However, fruit germination and seedling establishment is curtailed due to their salinity-sensitivity.
\end{abstract}

Key words: floral sexual functions, fruit set, germination, mixed breeding system, seedling

\section{Introduction}

Lumnitzera Willd. (Combretaceae R. Br.) is a non-viviparous Indo-West Pacific mangrove genus of two evergreen tree species with similar vegetative appearance, $L$. littorea (Jack) Voigt and L. racemosa Willd.. The genus was named in honor of the Hungarian botanist and physician, István [Stephan] Lumnitzer (17501806). The two species occur in Cambodia,
India, Indonesia, Malaysia, China, New Guinea, Philippines, Singapore, Sri Lanka, Thailand, Vietnam, northern Australia, and on various western Pacific islands (Shu, 2007). Lumnitzera littorea is distributed in tropical Asia and Australia. In China, it is an endangered species confined to restricted regions of Hainan Province (Su et al., 2007). 
Tomlinson (1986) noted that L. littorea is an out-crossing, non-viviparous species, and successful fruit dispersal relies on suitable ocean currents. Tomlinson et al. (1978) stated that L. littorea is pollinated predominantly by honeyeaters such as the graceful honeyeater (Meliphaga gracilis (Gould), various sunbirds, bees and wasps. Bird pollination is indicated in this species by the red flower colour and the abundant nectar that accumulates to one side of the calyx tube. The flowers are longer and the petals are directed forward, orienting the bill of the bird and protecting the nectar from most insects. The stamens are directed forward to touch the bill of the bird. The terminal inflorescences accommodate large pollinators.

Lumnitzera racemosa is characteristic of landward, highly salinity areas in the mangroves occurring from East Africa to Tonga in the Pacific Ocean, and in north Australia (Su et al., 2006). Later study by Shu (2007) reported that it occurs in open remnant mangrove forests along sea shores, estuaries, lagoon sides, saltwater swamps, swamps, and swampy meadows on sandy soils. He also mentioned that there are two varieties in this species namely var. racemosa with white flowers and var. lutea (Gaudich.) Exell with yellow flowers; the former occurs throughout the range of the species while the latter is confined to Timor Island of Indonesia. Murugan et al. (2004) reported that $L$. racemosa is a basin or interior mangrove species growing luxuriantly in certain pockets of coastal belts of Kerala in India, characterized by infrequent tidal action, varied salinity, and low water turbulence. Tomlinson et al. (1978) reported that $L$. racemosa is pollinated by dayactive insects but these authors did not provided detailed information on the pollination ecology of this species. Since this species plays a crucial role in maintaining structural and functional integrity of mangrove forest ecosystem, the knowledge of pollination ecology is essential to understand its sexual reproductive system and regeneration ecology. Therefore, the present study was contemplated to detail the pollination ecology of $L$. racemosa based on field studies carried out at Coringa mangrove forest, Andhra Pradesh State, India.

\section{Materials and Methods}

Study site: The Coringa mangrove forest is located in the Godavari estuary in the East
Godavari District, Andhra Pradesh, between $16^{\circ} 39^{\prime}-17^{\circ} 00^{\prime} \mathrm{N}$ and $82^{\circ} 14^{\prime}-82^{\circ} 23^{\prime} \mathrm{E}$. The total area of the forest is $316 \mathrm{sq}$. $\mathrm{km}$ in which 235.7 sq. $\mathrm{km}$ is in the Coringa Wildlife Sanctuary. This sanctuary has three reserve forests: Coringa R.F., Coringa Extension R.F., and Bhairavapalem R.F. The mangrove cover in these three forests is not directly connected with the Bay of Bengal. The non-sanctuary mangrove area has six reserve forests, namely the Rathikalava, Masanitippa, Matlatippa, Balusutippa, Kothapalem, and Kandikuppa reserve forests. This non-sanctuary area is connected to the sea. Lumnitzera racemosa occurs in the oligo- and meso-haline zones with salinity readings ranging from 0.5 to $18 \%$. It is not found in the Bhairavapalem and Balusitippa reserve forests but is distributed in all other seven forests. Large populations of this species occur in the Kothapalem and Kandikuppa reserve forests while a few individuals with scattered distribution are found in the other five. The plants found in its association include Ceriops decandra (Griff.) W. Theob., Avicennia marina (Förssk.) Vierh., Aegiceras corniculatum (L.) Blanco, and Excoecaria agallocha L. In Kothapalem, it is mixed mostly with Scyphiphora hydrophyllacea C.F. Gaertn. which is confined to this reserve forest only.

\section{Floral presentation and reproductive traits:} The populations of Lumnitzera racemosa occurring in Kothapalem and Kandikuppa were used for the present study during 2012-2014. Regular field trips were conducted to track the flowering season with intensive field studies made at weekly intervals during the flowering and fruiting seasons. Floral morphological characteristics were described based on 25 flowers collected at random from five trees. Quantification of the number of flowers produced per inflorescence and the duration of inflorescence life were determined by tagging ten randomly selected inflorescences which had not initiated flowering, and then followed daily until they ceased flowering permanently. Anthesis was initially recorded by observing marked mature buds in the field. Later, the observations were repeated three or four times on different days during $0600-1800 \mathrm{~h}$ to obtain an accurate anthesis schedule. Similarly, the mature buds were followed to record the time of anther dehiscence. The presentation pattern of pollen was noted by determining how anthers dehisced; such observations were 
confirmed by observing the anthers under a 10x hand lens. Twenty five mature but undehisced anthers were collected from different plants and placed in a Petri dish. Later, a single anther was taken out and placed on a clean microscope slide $(75 \times 25 \mathrm{~mm})$ and dabbed with a needle in a drop of lactophenol-aniline-blue. The anther tissue was then observed under a microscope for pollen, if any, and if pollen was present, the pollen mass was removed and drawn into a band, and the total number of pollen grains was counted under a compound microscope (400x). This procedure was followed for counting the number of pollen grains in each anther collected. Based on these counts, the mean number of pollen grains produced per anther was determined. The mean pollen output per anther was multiplied by the number of anthers in the flower to obtain the mean number of pollen grains per flower. The characteristics of pollen grains were also recorded. The pollenovule ratio was determined by dividing the average number of pollen grains per flower by the number of ovules per flower. The value thus obtained was taken as pollen-ovule ratio (Cruden, 1977). The presence of nectar was determined by observing the mature buds and open flowers. The volume of nectar from 20 flowers collected at random from five trees was measured. Then, the average volume of nectar per flower was determined and expressed in $\mu 1$. The flowers used for this purpose were bagged at a mature bud stage, opened after anthesis, and the nectar drawn into a micropipette to measure nectar volume. Nectar sugar concentration was determined using a Hand Sugar Refractometer (Erma, Japan). For the analysis of sugar types, the paper chromatography method described by Harborne (1973) was followed. Nectar was placed on Whatman No. 1 filter paper along with standard samples of glucose, fructose and sucrose. The paper was run ascendingly for 24 hours with a solvent system of n-butanol-acetone-water (4:5:1), sprayed with aniline oxalate spray reagent and dried at $120{ }^{\circ} \mathrm{C}$ in an electric oven for 20 minutes to develop spots from the nectar and the standard sugars. Then, the sugar types present, and also the most dominant sugar type, were recorded based on the area and colour intensity of the spot. Nectar amino acid types were also recorded as per the paper chromatography method of Baker \& Baker (1973). Nectar was spotted on Whatman No. 1 filter paper along with the standard samples of nineteen amino acids, namely, alanine, arginine, aspartic acid, cysteine, cystine, glutamic acid, glycine, histidine, isolecuine, leucine, lysine, methionine, phenylalanine, proline, serine, threonine, tryptophan, tyrosine, and valine. The paper was run ascendingly in a chromatography chamber for 24 hours with a solvent system of n-butanol-glacial acetic acidwater $(4: 1: 5)$. The chromatogram was detected with $0.2 \%$ ninhydrin reagent and dried at $85^{\circ} \mathrm{C}$ in an electric oven for 15 minutes for the development of spots from the nectar and the standard amino acids. The developed nectar spots were compared with the spots of the standard amino acids, and the amino acid types recorded. The stigma receptivity was observed visually and by $\mathrm{H}_{2} \mathrm{O}_{2}$ test. In the visual method, the stigma physical state (wet or dry) and duration was recorded receptivity. $\mathrm{H}_{2} \mathrm{O}_{2}$ test as given in Dafni et al. (2005) was followed for noting stigma receptivity period.

Pollinators: The insect species visiting the flowers were observed visually and, when captured, using an Olympus Binoculars (PX35 DPSR Model). Their foraging activity was confined to daytime observations only and were observed for their foraging behaviour such as mode of approach, landing, probing behaviour, the type of forage they collect, contact with essential organs to result in pollination, and inter-plant foraging activity critical to crosspollination. The foraging insects were captured during $1000-1200 \mathrm{~h}$ and brought to the laboratory. For each insect species, ten specimens were captured and each specimen was washed first in ethyl alcohol, the contents stained with aniline-blue on a glass slide, and the results observed using a microscope to count the number of pollen grains. In case of pollen collecting insects, pollen loads on their corbiculae were separated prior to washing. From this, the average number of pollen grains carried by each insect species was calculated to ascertain the pollen carryover efficiency of different insect species.

Breeding system: Mature flower buds of some inflorescences on different individuals were tagged and enclosed in butter paper bags for breeding experiments. The number of flower buds used for each mode of pollination is summarized in Table 1. The stigmas of flowers were pollinated with the pollen of the same flower manually by using a brush; they were 
bagged and followed to observe fruit set in manipulated autogamy. The flowers were finemesh bagged without hand pollination to observe fruit set in spontaneous autogamy. The emasculated flowers were hand-pollinated with the pollen of a different flower on the same plant; they were bagged and followed for fruit set in geitonogamy. The emasculated flowers were pollinated with the pollen of a different individual plant; they were bagged and followed for fruit set in xenogamy. If fruit set was obtained, the percentage of fruit set was calculated for each mode. The flowers/ inflorescences were tagged on different plant species prior to anthesis and followed for fruit/seed set the rate for open-pollinations.

Table 1: Results of breeding experiments on Lumnitzera racemosa

\begin{tabular}{lccc}
\hline Breeding system & $\begin{array}{c}\text { No. of } \\
\text { flowers } \\
\text { pollinated }\end{array}$ & $\begin{array}{c}\text { No. of } \\
\text { flowers set } \\
\text { fruit }\end{array}$ & $\begin{array}{c}\text { Fruit } \\
\text { set } \\
(\%)\end{array}$ \\
\hline $\begin{array}{l}\text { Autogamy } \\
\text { (bagged) }\end{array}$ & 58 & 12 & 21 \\
$\begin{array}{l}\text { Autogamy } \\
\text { (hand-pollinated }\end{array}$ & 60 & 21 & 35 \\
$\begin{array}{l}\text { \& bagged) } \\
\text { Geitonogamy }\end{array}$ & 40 & 26 & 65 \\
$\begin{array}{l}\text { Xenogamy } \\
\text { Open pollinations }\end{array}$ & 50 & 41 & 82 \\
\hline
\end{tabular}

Fruiting ecology: Fruit maturation period was recorded by making field trips to the study sites during the entire fruiting period. Careful observations were made of fruit dispersal by ocean currents and tides. Fruit and seed characteristics were recorded in detail based on 50 fruits collected from ten trees distributed randomly in the study sites.

Photography: Plant, flower and fruit details together with insect foraging activity on flowers were photographed with Nikon D40X Digital SLR (10.1 pixel) and TZ240 Stereo Zoom Microscope with SP-350 Olympus Digital Camera (8.1 pixel).

\section{Results}

Phenology: Lumnitzera racemosa is an evergreen, medium-sized, erect and muchbranched tree that grows up to $6 \mathrm{~m}$ high (Fig. 1A). Ceriops decandra, Avicennia marina, Aegiceras corniculatum and Excoecaria agallocha usually grow along with $L$. racemosa in all areas of its occurrence in the Coringa mangroves except for the Kothapalem site where it is associated with Scyphiphora hydrophyllacea only. It sheds leaves continually but leaf shedding is prominent during May, which is followed by a profuse leaf flushing during June and July when rains occur. Young plants show sparse flowering (Fig. 1B). The flowering occurs en masse from the second week of July to the second week of August. An individual tree flowers for 25-28 days. Inflorescence is an axillary spike, $2-3 \mathrm{~cm}$ long and produces $25.8 \pm 11.3$ (range 10-46) flowers over a period of 12-16 days (Fig. 1C).

The Flower: Flowers of Lumnitzera racemosa are pedicellate, small $(15 \mathrm{~mm}$ long, $6 \mathrm{~mm}$ wide), milky white in color, tubular, odourless, bisexual and actinomorphic. The persistent calyx is green-coloured, glabrous and tube-like with the lower half flattened terminating in five sepal lobes at the apex (Fig. 1D). The milky white and coriaceous corolla is $6 \mathrm{~mm}$ long, basally tubular and apically divided into five spreading, oblong, petals that alternate with the sepals. The 10 somewhat exserted stamens are $6 \mathrm{~mm}$ long, free and creamy white (Fig. 1E), arranged in two whorls of five each at two different heights, one whorl at the base of the petal and the other at the base of the lobes of the calyx. The anthers are bilobed, $1 \mathrm{~mm}$ long, light yellow, exserted, extrorse, and dorsifixed. The 1-locular ovary is inferior with 3-5 pendulous ovules suspended from a slender placenta hanging from the upper end of ovarian chamber (Fig. 1F). The style is inserted in the center, $6 \mathrm{~mm}$ long, creamy white, broad at the base and tapering at the tip; the stigma is minute, creamy white and slightly hood-like.

Floral biology: The mature buds open at 0700$1100 \mathrm{~h}$ by splitting the petal lobes. Petals expand and spread horizontally but do not reflex; then the stamens, style and stigma are exposed. The style and stigma extend beyond the inner whorl of stamens but do not exceed the height of outer whorl. At anthesis, the anthers dehisce by longitudinal slits with the inner whorl dehiscing about 30 minutes before the anthers of the outer whorl. The pollen output per anther is $1485.5 \pm 144.1$ (range 1133-1,675) and per flower is 14855 pollen grains. Pollen grains are 3-zonocolporate, 33.2 $\mu \mathrm{m}$ long, prolate spheroidal, hexangular, pseudocolpi with flattened granulate, dull white, and the exine reticulate and powdery. The pollen-ovule ratio is 2971:1. The stigma 
attains receptivity on the second and third day of anthesis. A flower produces $1.41 \pm 0.2$ (Range 0.9-1.6) $\mu 1$ of nectar in the calyx tube. The nectar sugar concentration is $24.7 \pm 2.35 \%$ (range 19.5-26.8\%) and the common sugars include glucose and fructose with the former as dominant. The total sugar content in the nectar of a flower is $0.37 \pm 0.06$ (range $0.24-0.46$ ) $\mathrm{mg}$. The nectar contains five essential amino acids (arginine, histidine, lysine, threonine and tryptophan), and six non-essential amino acids (tyrosine, aspartic acid, cystine, cysteine, alanine and proline). The corolla together with stamens drops off on the fourth day. The style and stigma are persistent and remains attached to the tip of the growing fruit. The calyx is persistent, gradually bulges and encloses the fruit.

Breeding systems: The results of breeding systems indicate that the flowers of Lumnitzera racemosa are self-compatible and selfpollinating. The fruit set is $21 \%$ in spontaneous autogamy, 35\% in hand-pollinated autogamy, $65 \%$ in geitonogamy, $82 \%$ in xenogamy, and $89 \%$ in open pollination (Table 1). Fruits produced per inflorescence in open pollination are $23 \pm 7.74$ (range 7-49).

Pollination mechanism and pollinators: The flowers of Lumnitzera racemosa are unspecialized and the stamens and stigma are exposed when the petals expand horizontally. They were foraged by bees, wasps and butterflies consistently from 0800 to $1700 \mathrm{~h}$ with most activity during 0900-1200 h. The bees were Apis dorsata, Apis cerana, A. florea, Nomia sp., Amegilla sp., and Megachile sp. The wasps were Odynerus sp., Vespa cincta, and Rhynchium sp. The butterflies were Pachliopta hector, Catopsilia pomona, C. pyranthe, Cepora nerissa, Hypolimnas misippus, $H$. bolina, Tirumala limniace, and T. septentrionis (Table 2). All of the bees collected pollen and nectar in the same and/or in a different foraging visit while wasps and butterflies collected only nectar. The simultaneously foraging activity of all of these insects compelled them to visit different conspecific plants occurring in the same area or at a different area within the mangrove forest. Their hectic foraging activity was considered to be affecting both self- and/or cross-pollination. Bees and wasps usually landed on individual flowers to probe the flower for the forage, and while doing so they invariably contacted the stamens and stigma with their head and ventral side. Such a contact was found to result in the transfer of pollen to the bee's body. Butterflies landed on the inflorescence and then inserted their proboscis into individual flowers during which there was contact between flower sex organs and forehead and proboscis, and this contact was found to be effective for both self- and crosspollination. Of the total foraging visits made by these insects, bee visits constituted $34 \%$, wasp visits $15 \%$, and butterfly visits $51 \%$ (Figs. $2-4$ ). Body washings of these insects revealed the presence of pollen grains, the mean number varying from 102 to 643.2 in case of bees, 68.7 to 78.9 in case of wasps, and 36.9 to 63.1 in case of butterflies (Table 3). The results indicated that each insect species is a pollen carrier and the pollen carry-over capacity is related to the body size in case of bees and wasps and proboscis length, and to some extent head size in butterflies.

Table 2: List of insect foragers on Lumnitzera racemosa, $\mathrm{P}$, pollen; $\mathrm{N}$, nectar

\begin{tabular}{|c|c|c|}
\hline Family & Species & $\begin{array}{l}\text { Forage } \\
\text { sought }\end{array}$ \\
\hline \multicolumn{3}{|l|}{ Hymenoptera } \\
\hline \multirow{3}{*}{ Apidae } & Apis dorsata & $\mathrm{P}+\mathrm{N}$ \\
\hline & Apis cerana & $\mathrm{P}+\mathrm{N}$ \\
\hline & Apis florea & $\mathrm{P}+\mathrm{N}$ \\
\hline Halictidae & Nomia sp. & $\mathrm{P}+\mathrm{N}$ \\
\hline Anthophoridae & Amegilla sp. & $\mathrm{P}+\mathrm{N}$ \\
\hline Megachilidae & Megachile sp. & $\mathrm{P}+\mathrm{N}$ \\
\hline \multirow{3}{*}{ Vespidae } & Odynerus sp. & $\mathrm{N}$ \\
\hline & Vespa cincta & $\mathrm{N}$ \\
\hline & Rhynchium sp. & $\mathrm{N}$ \\
\hline \multicolumn{3}{|l|}{ Lepidoptera } \\
\hline Papilionidae & Pachliopta hector & $\mathrm{N}$ \\
\hline \multirow{3}{*}{ Pieridae } & Catopsilia pomona & $\mathrm{N}$ \\
\hline & Catopsilia pyranthe & $\mathrm{N}$ \\
\hline & Cepora nerissa & $\mathrm{N}$ \\
\hline \multirow{4}{*}{ Nymphalidae } & Hypolimnas misippus & $\mathrm{N}$ \\
\hline & Hypolimnas bolina & $\mathrm{N}$ \\
\hline & Tirumala limniace & $\mathrm{N}$ \\
\hline & Tirumala septentrionis & $\mathrm{N}$ \\
\hline
\end{tabular}

Fruiting behavior: Pollinated and fertilized flowers initiate fruit development immediately and take 20-25 days to produce mature fruits. Individual inflorescences show maximum fruit set (Fig. 5). Fruit dispersal occurs during October-November. The fruit is $15-20 \mathrm{~mm}$ long, vase-shaped, 1-seeded, hard, glossy, 
corky, flattened basally, and yellowish green initially then brown at maturity. Seed remains within the fruit and is exposed only after the decay of the fruit wall. The fruit is waterbuoyant and dispersed by tidal currents. The fruit becomes fibrous after floating and finally settles in the soil during low tide period. The success rate of seed germination and subsequent seedling recruitment could not be assessed due to their non-viviparous mode of reproduction. Casual field observations, however, indicated the occurrence of a few young plants near parental population and almost non-occurrence of young plants in other areas where parental plants do not occur.

Table 3: Pollen pick-up efficiency of foraging insects on Lumnitzera racemosa; sample size $=10$.

\begin{tabular}{lcc}
\hline \multicolumn{1}{c}{ Insect species } & Range & Mean \pm S.D \\
\hline Apis dorsata & $476-870$ & $643.2 \pm 95.2$ \\
Apis cerana & $321-569$ & $432.1 \pm 68.1$ \\
Apis florea & $81-286$ & $184.6 \pm 82.06$ \\
Megachile sp. & $64-197$ & $117.21 \pm 49.06$ \\
\hline Nomia sp. & $47-158$ & $102.1 \pm 37.53$ \\
Odynerus sp. & $32-146$ & $78.9 \pm 34.86$ \\
\hline Amegilla sp. & $110-210$ & $152.4 \pm 41.0$ \\
Rhynchium sp. & $38-123$ & $73.5 \pm 31.02$ \\
\hline Vespa cincta & $26-135$ & $68.7 \pm 40.17$ \\
\hline Pachliopta hector & $31-104$ & $63.1 \pm 23.93$ \\
Catopsilia pomona & $24-92$ & $51.8 \pm 25.25$ \\
Catopsilia pyranthe & $28-74$ & $48.4 \pm 16.83$ \\
\hline Cepora nerissa & $13-67$ & $38.9 \pm 20.08$ \\
Hypolimnas misippus & $28-95$ & $53.6 \pm 22.13$ \\
\hline Hypolimnas bolina & $11-65$ & $36.9 \pm 17.59$ \\
Tirumala limniace & $21-83$ & $48.1 \pm 18.77$ \\
\hline Tirumala septentrionis & $16-78$ & $51.4 \pm 23.51$ \\
\hline
\end{tabular}

\section{Discussion}

Lumnitzera racemosa is a non-viviparous evergreen tree species that occurs in the oligoand meso-haline zones of the Coringa mangrove forest. It is poorly distributed in the entire mangrove forest except in two places where large populations occur. In these areas, $L$. racemosa is characteristically a landward plant with distribution extended up to mesohaline areas with varied salinity and experiencing infrequent tidal action. This finding is in conformity with the reports on the distribution of this species in other areas from East Africa to Tonga in the Pacific Ocean, northern Australia (Su et al., 2006), and along Kerala coast in India (Murugan et al., 2004).
Furthermore, L. racemosa grows successfully in association with Ceriops decandra, Avicennia marina, Aegiceras corniculatum, and Excoecaria agallocha in all areas of its occurrence in the study area except one site, Kothapalem, where it is associated only with Scyphiphora hydrophyllacea. In all the areas of its occurrence $L$. racemosa grows successfully in harsh conditions. Similarly, Tomlinson et al. (1978) also reported that $L$. racemosa grows successfully in harsh conditions in association with Ceriops and Avicennia in the inner mangrove forests of Queensland. The unique finding in this study is that the ability of this species to grow in the association of a large population of $S$. hydrophyllacea.

Shu (2007) reported that Lumnitzera racemosa is represented by two varieties, var. lutea with yellow flowers and var. racemosa with white flowers. In the study area, only the var. racemosa is known. Tomlinson et al. (1978) reported that $L$. racemosa flowers from October to March in Queensland but at the present study area, this species flowers massively and synchronously for one month only from midJuly to mid-August. Given the short-flowering season, the synchronous massive flowering pattern is advantageous in attracting a wide variety of insects which otherwise visit other co-flowering species in the mangrove forest. The plants that flower concurrently include species of Avicennia L., Bruguiera Sav., Ceriops decandra, Rhizophora L., Derris trifoliata Lour., and Excoecaria agallocha; of these Bruguiera, Ceriops and Rhizophora are year-long bloomers but show profuse flowering during the flowering period of $L$. racemosa. Avicennia, Derris and Excoecaria flowers attract certain of the insects that visit $L$. racemosa. Therefore, it is necessary for $L$. racemosa to display the observed flowering pattern to attract insect pollinators in the presence of other co-flowering plants to ensure maximize fruit set through sexual reproduction.

$\mathrm{Su}$ et al. (2007) reported that Lumnitzera littorea is an out-crossing species. But these authors did not mention any further details. Tomlinson et al. (1978) noted that L. racemosa may be self-compatible and suggested that experimental work was needed to confirm this. The present study indicates that $L$. racemosa has a mixed breeding system that enables it to reproduce through self and cross-pollination, 
the latter being the predominant mode of pollination through which the plant sets the highest fruit set. The pollen-ovule ratio also supplements the function of this breeding system (Cruden, 1977). Further, the plant is capable of setting fruit through spontaneous autogamy by gravitational pollination which occurs due to the fall of pollen from the dehisced anthers onto the papillose stigma that is situated slightly below the upper whorl of anthers. As the flowering season of the plant falls during rainy season, it is most likely that rain drops/water falling in the flowers also contribute to autogamy by gravitational pollination. The flowers are morphologically bisexual but functionally temporally dioecious due to protandry and the non-receptive state of the stigma on the first day of anthesis and stigma receptivity on the following two days. The fruit set through spontaneous autogamy is an indication of pollen viability on the second day or even the third day of flower life. This is in conformity with the supposition made by Tomlinson et al. (1978) that in L. racemosa, the pollen is present in the anthers only on the day the flower opens while the stigma appears to be receptive on subsequent days. These authors also stated that as a result of this marked protandry, individual flowers are probably not capable of self-pollination. But, this study suggests that individual flowers are capable of self-pollination due to gravitational pollination and it is substantiated by the occurrence of fruit set in bagged flowers. The highest natural fruit set rate of $89 \%$ recorded in L. racemosa is a result of the function of all modes of pollination and fructification of fertilized flowers nourished by resource-rich environment. As a result, most, if not all, of the flowers in a spike end up in the formation of fruits. This study substantiates the report by Tomlinson et al. (1978) that fruit set is high, probably over 50 percent in many trees, and even on isolated individuals, with all the flowers in a head setting fruit.

Tomlinson et al. (1978) reported that in Lumnitzera littorea, the flowers borne in terminal inflorescences are red, erect, slightly zygomorphic, effectively lengthening the tube somewhat and providing some protection from short-tongued insects. These floral structural characteristics are adapted for bird pollination. In line with this, the flowers are specifically pollinated by sunbirds and honeyeaters and are also visited by bees and wasps. These authors also mentioned that $L$. racemosa is frequently visited by wasps, bees, butterflies and diurnal moths. Of these insects, wasps are the most common foragers and are aggressive in chasing away other flower visitors foraging simultaneously on the flowers. In the present study, it is found that the characters related to pollination by generalized flower-visiting insects in $L$. racemosa are actinomorphy, namely the white spreading petals and the small volume of nectar secreted into the shallow calyx cup. The nectar is easily accessible to insects due to a broad and spacious corolla tube. The stamens are positioned to one side to promote contact by foraging insects that landed on the reflexed petals or other flowers. These characters constitute the syndrome of entomophily (Faegri \& van der Pijl, 1979). The axillary position of such flowers is suited to accommodate the foraging of even small pollinators such as insects (Tomlinson et al., 1979). In this study, L. racemosa is accordingly pollinated by bees while collecting pollen and nectar, wasps and butterflies while collecting nectar. Since a variety of insects forage simultaneously on individual trees, there would be forage shortage soon and multiple visits to the same flowers are neither economical nor rewarding. In effect, pollinators fly to other conspecific trees occurring in the area or elsewhere within the mangrove forest to visit as many flowers as possible to collect the limited forage to the extent possible. Such a conspecific inter-tree foraging behavior exhibited by all these three categories of insects maximizes the rate of out-crossing and enhances fruit set rate. Insect activity is heavily concentrated on the flowers of $L$. racemosa although other mangrove plants flower simultaneously and hence suggests that it is a preferred floral source for insects. The nectar is a source of five amino acids out of ten essential amino acids required by insects (DeGroot, 1953). It is also a source of six non-essential amino acids. Since bees concentrated on this pollen source, it appears to be an important source of protein for them.

In Lumnitzera racemosa, mature fruits are invariably 1-seeded despite the production of three to five ovules in the ovary suggesting that it is an inherent character of the plant to produce a single seed per fruit. Despite the highest natural fruiting rate in this species, its 
natural regeneration is low which could be due to the reasons cited by Tomlinson (1986) that a high percentage of mature fruits are commonly empty due to abortion of embryos and sometimes also because embryos are eaten by small grubs that originate from eggs laid by the parent insect early in fruit development. But, field studies are needed for confirmation of these suggestions. In normally formed fruits, the seed is well protected by the hard layer of sclerenchyma tissue inside the outer corky or fleshy layers of the fruit wall. Fallen mature fruits become fibrous after floating in water (Ye et al. 2004) and the fibrous nature of the fruit helps to disperse the fruit through ocean currents or tides. Tomlinson (1986) states that fruits of $L$. racemosa dispersed by water lose the softer outer layers thereby exposing the sclerenchymatous fibers and hence floating fruits lose their viability. This could be the reason for the failure of normal fruits of $L$. racemosa to germinate and produce new plants in the study area. Selvam (2007) experimentally demonstrated that germination rate of seeds of $L$. racemosa decreases with increasing salinity. In this context, it is appropriate to state the regeneration from normal seeds that finally anchor in the sediment is relatable to the salinity levels which vary widely in mangrove environment. Erratic and insufficient rainfall, perhaps due to climate change, now appear to be increasing salinity levels due to reduced outflows of fresh water from Godavari River into its estuary and eventually into the sea at the Coringa mangrove forest.

Hamrick et al. (1991) stated that geographic range is strongly associated with the level of variation maintained at the species level. Breeding systems, vegetative reproduction, and pollinators also significantly influence the genetic diversity of a species. Widely distributed plant species tend to maintain more variation than more narrowly distributed species. Lumnitzera littorea which covers a wide geographic range throughout the IndoPacific region is restricted to Hainan in China. $\mathrm{Su}$ et al. (2007) reported that in this species, genetic variation is low at the population level in China in contrast to the high variation detected at the species level. The low genetic variation within populations in general is an ecological consequence of high habitat homogenization since mangrove species are constantly subjected to physiological stress caused by unstable growing conditions and their successful colonization to suitable areas might be associated with morphological, physiological, and reproductive adaptations (Lakshmi et al., 1997). But, the genetic variation in a population is least influenced by edaphic preferences and adaptations in mangroves (Su et al., 2007). In the present study, $L$. racemosa is maintaining large populations in two forest reserves while it has lost populations in other forest reserves where its individuals are few in scattered locations. The occurrence of isolated and fragmented individuals of L. racemosa in such mangrove forests could be related to the effects of natural calamities such as cyclone, storm and flood, and to the effects of man-made threats such as grazing by cattle and goat, overexploitation of juvenile fishes, felling for timber and firewood, human inhabitation, and pollution (Koteswaran, 1984; Banerjee et al., 1998).

\section{Recommendations}

Lumnitzera racemosa is a non-viviparous tree species. Only a few new plants emerge from seed at parental sites during rainy season. In our study area, the species has two large populations in two different forest reserves within the Coringa mangrove forest. Here, it supports a wide variety of insects including bees, wasps and butterflies by providing both pollen and/or nectar. In return, these insects affect both self- and cross-pollination. The plant with a mixed mating system is capable of setting fruit at $90 \%$ but most of the fruits appear to be either seedless or the embryos are fed upon by some unknown grubs. Normal fruits contain a single seed and disperse by ocean currents or tidal action. Natural regeneration rate is low which could be related to the loss of seed viability during dispersal and the sensitivity of seeds to salinity variations. In view of this, it is recommended that restoration activity should be carried out in these areas to populate them with Lumnitzera racemosa by partly using seeds of genetically similar donor populations collected from other areas (Tomlinson, 1986; Selvam, 2007) and partly using transplantation of a large number of seeds from long-established, large populations to maintain the maximum representation of genetic adaptability (Hamrick \& Godt, 1996) and to maintain the maximum representation of genetic adaptability (Su et al., 2007). The 
existing large populations should be protected by taking all possible measures within legal frameworks or else their population size could be reduced drastically and subjected to the risk of losing genetic flexibility by drift and shortterm lowering of fitness due to inbreeding depression. If the numbers of trees in these populations are already are too low and have already dropped below a critical threshold level, the inevitable populations will continue to decline in numbers and fitness, and it becomes increasingly likely to result in extirpation (Allnutt et al., 2003; Aaron \& John, 2003). Therefore, to maintain the potential to respond to new selection pressures brought about by environmental and land-use changes in the Coringa mangrove forest it is most important to monitor the existing large populations, and also scattered individuals of $L$. racemosa, in terms of their fitness since the survival of a species in this portion of its range in India, depends on its genetic variability.

\section{Literature Cited}

Aaron, R. and John, S.P., 2003. Conservation of the critically endangered Rumex rothschildianus as implied from AFLP diversity. Biological Conservation, 114: 299-303.

Allnutt, T., Newton, A.C., Premoli, A., and Lara, A., 2003. Genetic variation in the threatened South American conifer Pilgeradendron uviferum (Cupressaceae), detected using RAPD markers. Biological Conservation, 114: 245-253.

Baker, H. G. and Baker, I., 1973. Some anthecological aspects of evolution of nectarproducing flowers, particularly amino acid production in nectar. Pp. 243-264, In: Heywood, V.H. (ed.). Taxonomy and Ecology. Academic Press, London.

Banerjee, L.K., Ghosh, D. and Sastry, A.R.K., 1998. Mangroves, Associates and Salt Marshes of the Godavari and Krishna Delta. Botanical Survey of India, Kolkata: 128.

Cruden, R.W., 1977. Pollen-ovule ratios: A conservative indicator of breeding systems in flowering plants. Evolution, 31: 32-46.

Dafni, A., Kevan, P.G. and Husband, B.C., 2005. Practical Pollination Biology. Enviroquest Ltd., Ontario: 315.
DeGroot, A.P., 1953. Protein and amino acid requirements of the honey bee (Apis mellifera L.). Physiologia Comparata et Oecologia, 3: 197285.

Faegri, K. and van der Pijl, L., 1979. The Principles of Pollination Ecology. Pergamon Press, New York: 291.

Hamrick, J.L. and Godt, M.J.W., 1996. Conservation genetics of endemic plant species. Pp. 281-304, In: Avise, J.C. and Hamrick, J.L. (eds.). Conservation Genetics. Chapman and Hall, New York.

Hamrick, J.L., Godt, M.J.W., Muraswki, D.A., and Loveless, M.D., 1991. Correlations between species and allozyme diversity: Implications for conservation biology. Pp. 75-86, In: Falk, D.A. and Holsinger, K.E. (eds.). Genetics and Conservation of Rare Plants. Oxford University Press, New York.

Harborne, J.B., 1973. Phytochemical Methods. Chapman and Hall, London: 288.

Koteswaran, P., 1984. Climate and mangrove forests. Pp. 20-46, In: Anonymous (ed.). Report of the second introductory training course on mangrove ecosystems. UNPD and United Nations Educational, Scientific and Cultural Organisation, Goda, India.

Lakshmi, M., Rajalakshmi, S., Parani, M., Anuratha, C.S., and Parida, A., 1997. Molecular phylogeny of mangroves. I. Use of molecular markers in accessing the intraspecific genetic variability in the mangrove species Acanthus ilicifolius Linn. (Acanthaceae). Theoretical and Applied Genetics, 94: 1121-1127.

Murugan, K., Arunkumar, N.S., and Mohankumar, C., 2004. Purification and characterization of cinnamyl alcohol-NADPHdehydrogenase from the leaf tissues of a basin mangrove Lumnitzera racemosa Willd. Indian Journal of Biochemistry \& Biophysics, 41: 96101.

Selvam, V., 2007. Trees and Shrubs of the Maldives. Ministry of Fisheries, Agriculture and Marine Resources, Maldives: 239.

Shu, I.I., 2007. 1. Lumnitzera. Flora of China, 13: 309-310.

Su, G-H., Huang, Y-L., Tan, F-X., Ni, X-W, Tang, T., and Shi, S-H., 2006. Genetic variation in Lumnitzera racemosa, a mangrove species 
from the Indo-West Pacific. Aquatic Botany, 84: 341-346.

Su, G., Huang, Y., Tan, F., Ni, X., Tang, T., and Shi, S., 2007. Conservation genetics of Lumnitzera littorea (Combretaceae), an endangered mangrove, from the Indo-West Pacific. Marine Biology, 150: 321-328.

Tomlinson, P.B., 1986. The Botany of Mangroves. Cambridge University Press, New York: 413.

Tomlinson, P.B., Bunt, J.S., Primack, R.B., and Duke, N.C., 1978. Lumnitzera rosea (Combretaceae). Its status and floral morphology. Journal of Arnold Arboretum, 59: 342-351.

Ye, Y., Lu, C.Y., Wong, Y.S., and Tam, N.F.Y., 2004. Diaspore traits and inter-tidal zonation of non-viviparous mangrove species. Acta Botanica Sinica, 46: 896-906. 


\section{PLATE 9}
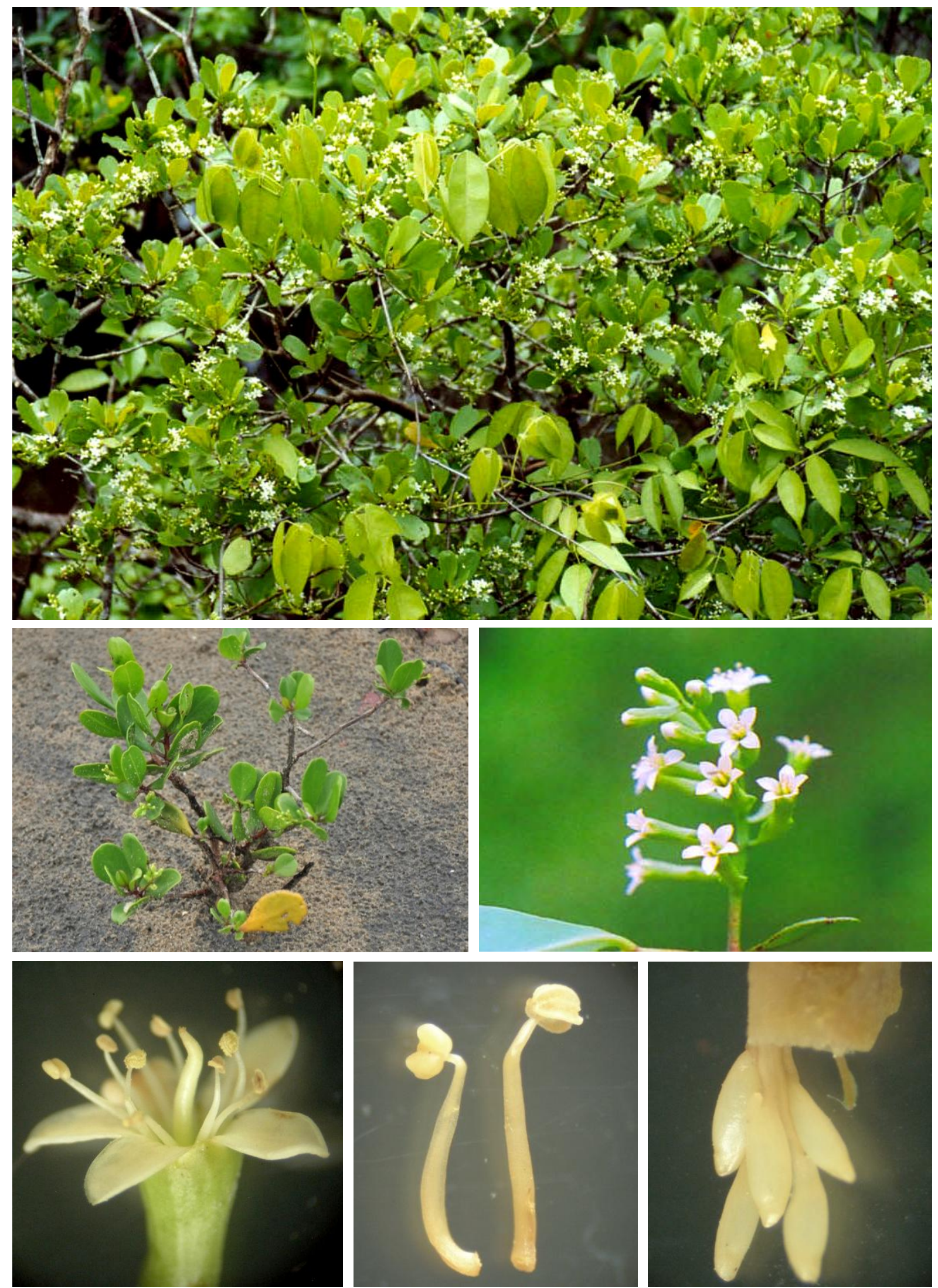

Figure 1: Lumnitzera racemosa $\mathbf{A}$, flowering branches; $\mathbf{B}$, young plant in flowering phase; $\mathbf{C}$, flowering inflorescences; D, flower showing relative positions of stamens and stigma; $\mathbf{E}$, stamens; F, 5-ovuled ovary. 


\section{PLATE 10}

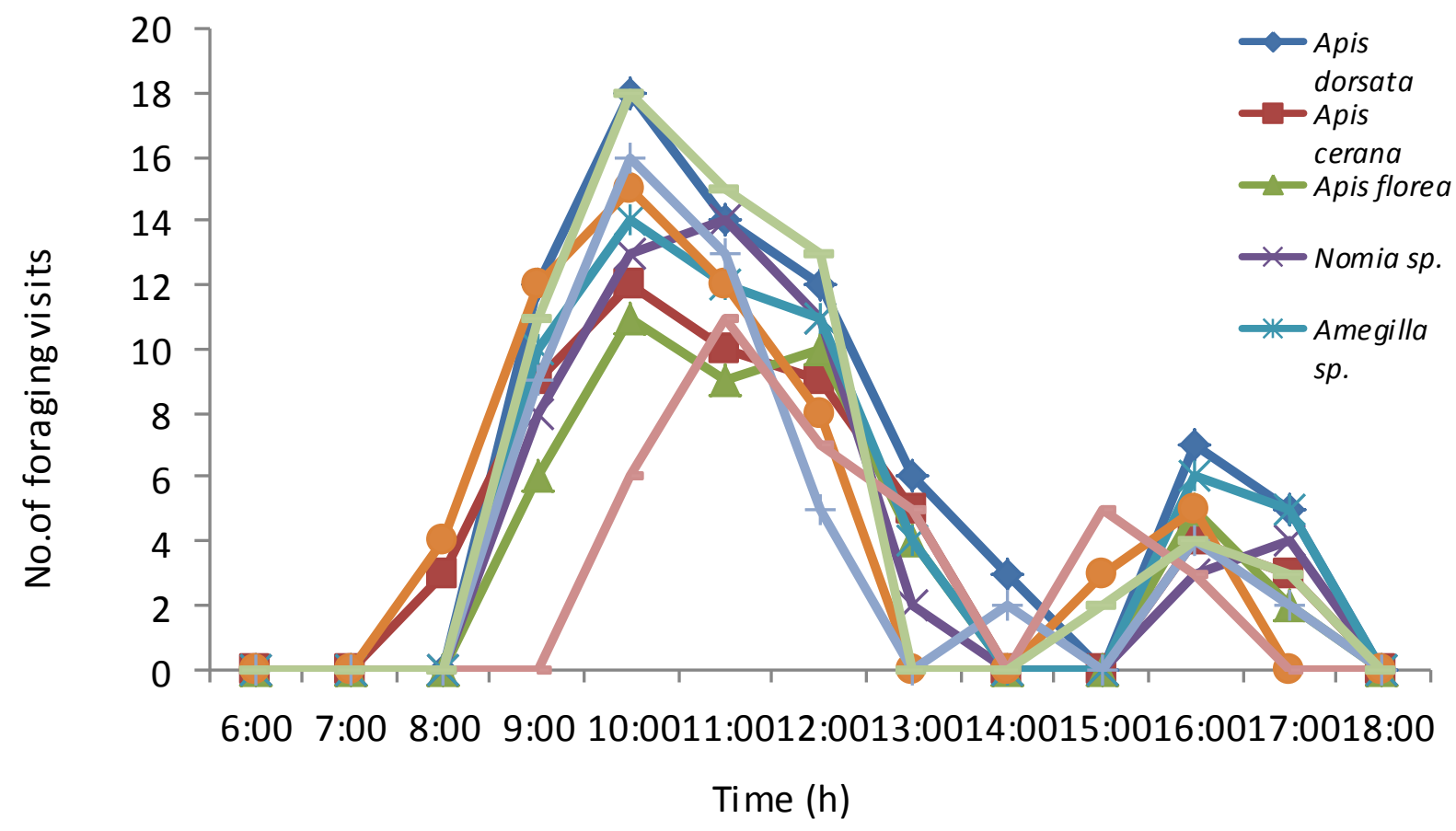

Figure 2: Hourly foraging activity of bees and wasps on Lumnitzera racemosa

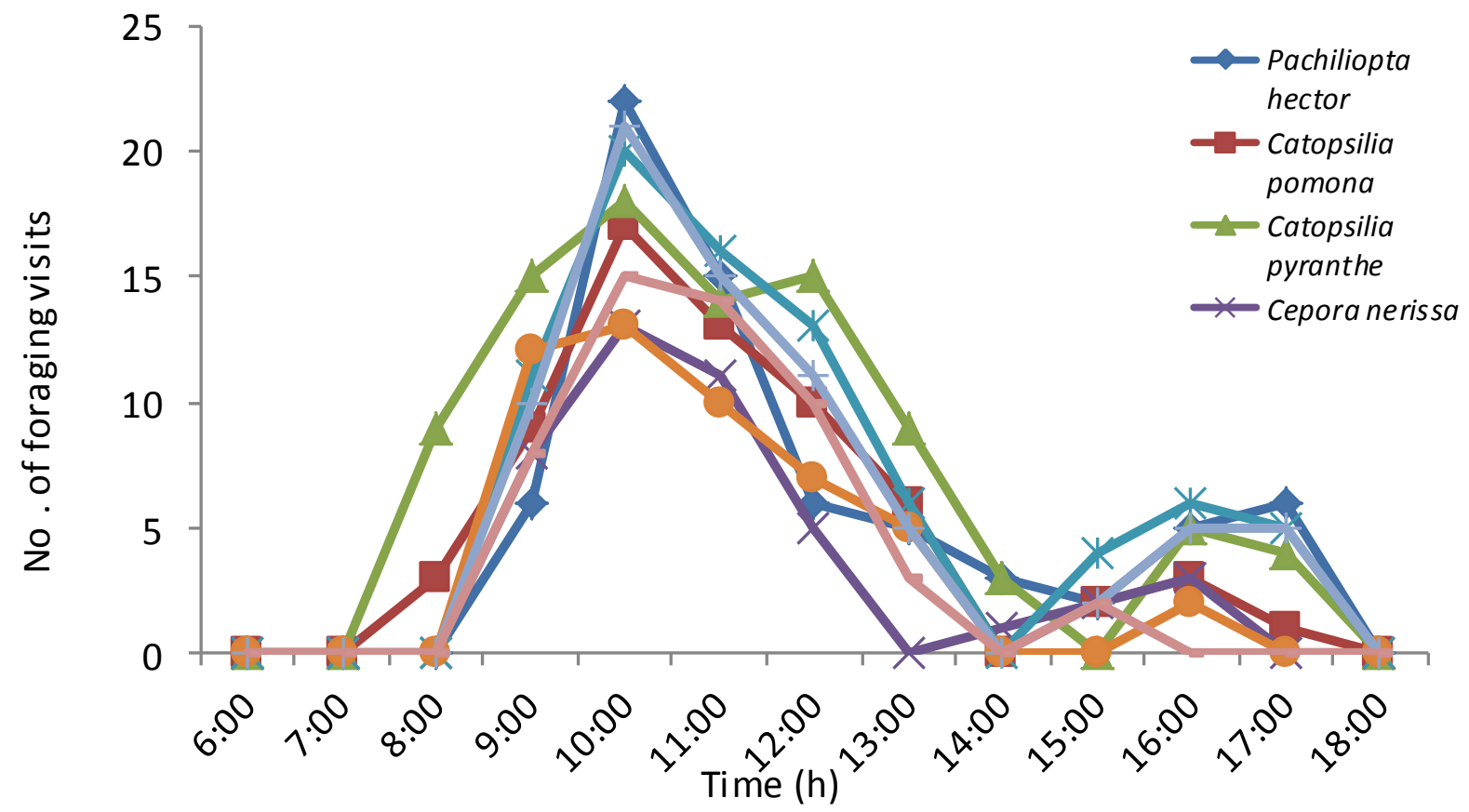

Figure 3: Hourly foraging activity of butterflies on Lumnitzera racemosa 


\section{PLATE 11}

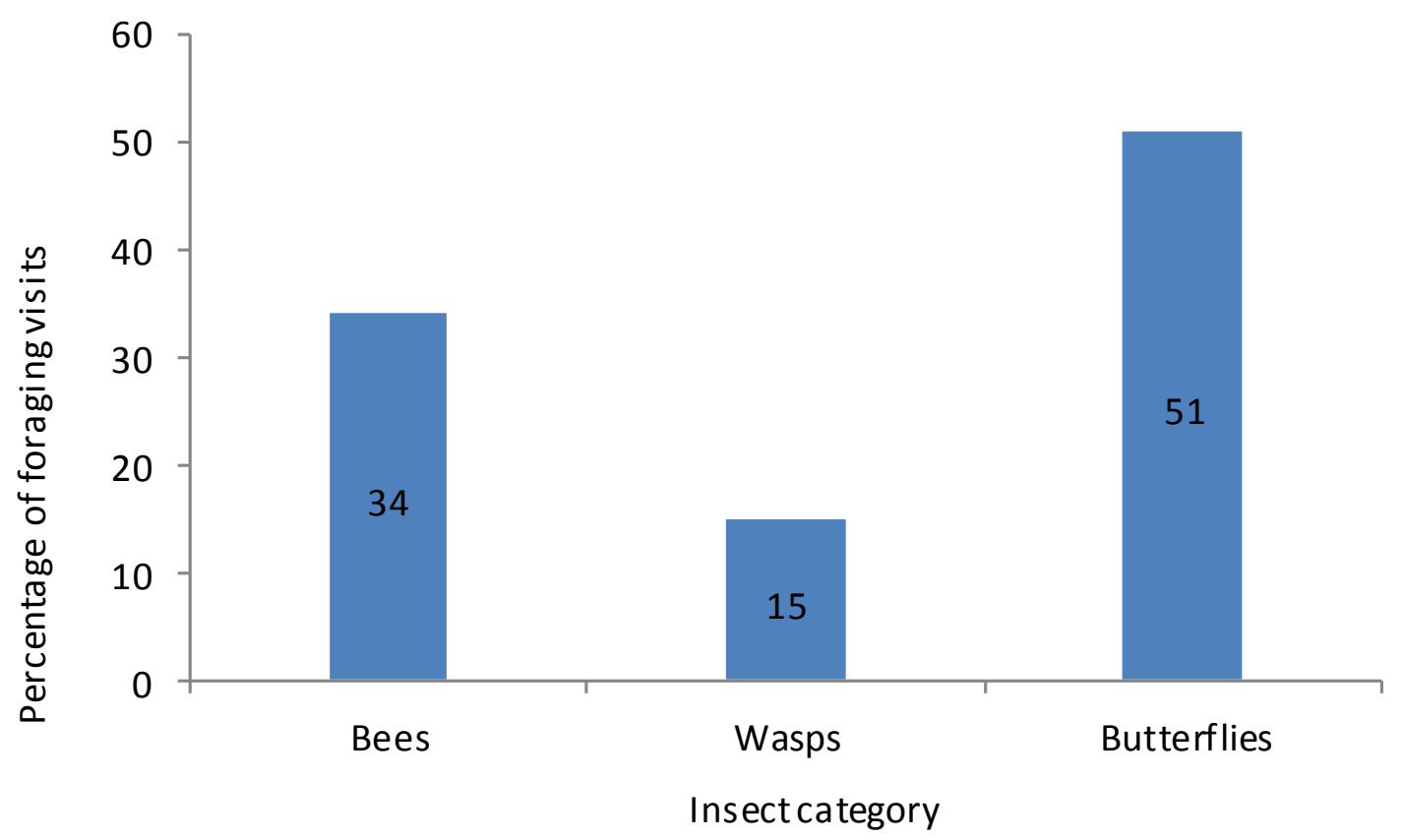

Figure 4: Percentage of foraging visits of different insect categories on Lumnitzera racemosa

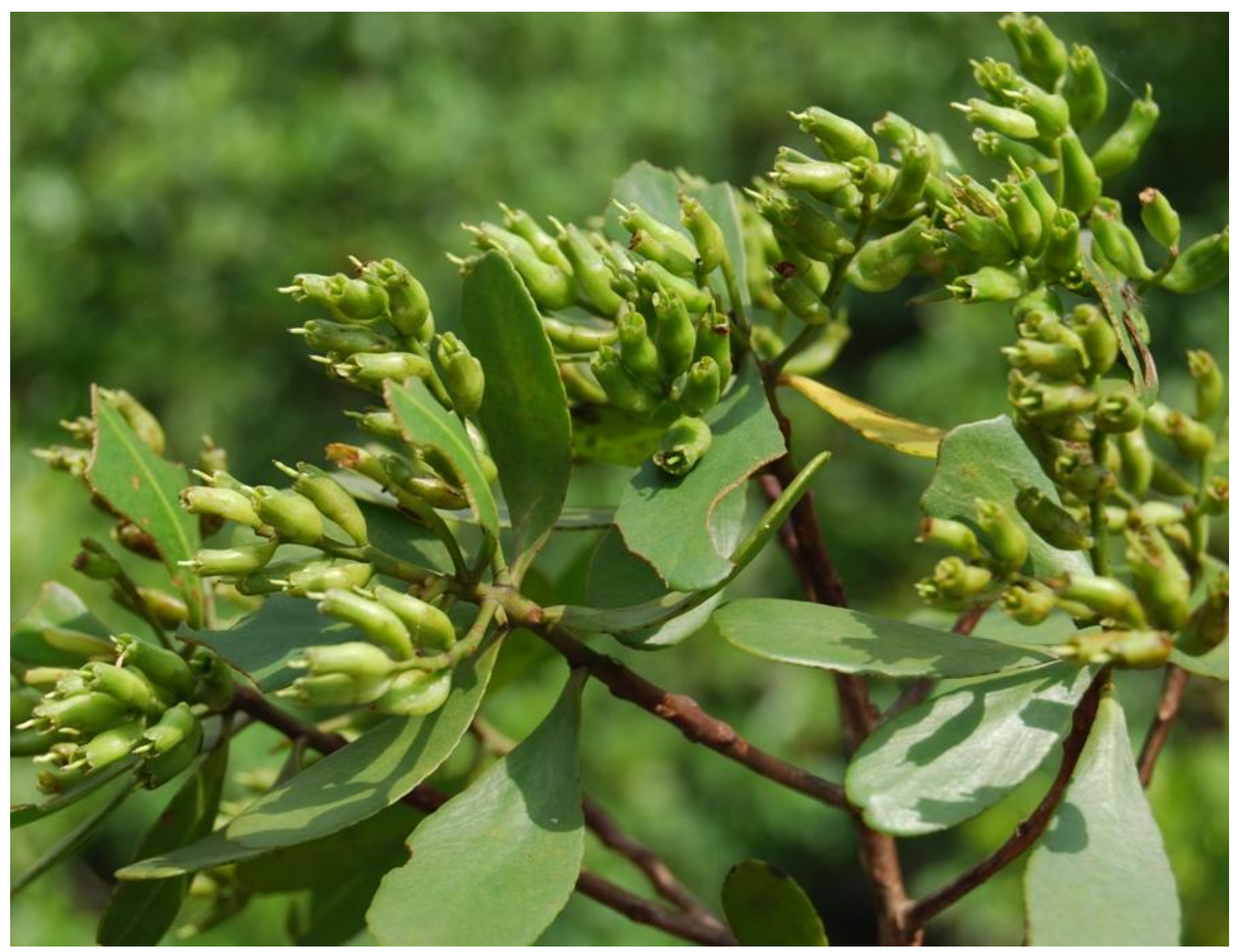

Figure 5: Fruited branches of Lumnitzera racemosa 